\title{
Autoimmune Thyroid Disorders
}

\author{
Rosalind Brown ${ }^{1}$ and Gary L. Francis ${ }^{2}$ \\ ${ }^{1}$ Pediatrics, Harvard Medical School, Boston, MA 02115, USA \\ ${ }^{2}$ Section of Pediatric Endocrinology and Metabolism, Children's Hospital of Richmond at the Virginia Commonwealth \\ University Health System, P. O. Box 980140, Richmond, VA 23098, USA \\ Correspondence should be addressed to Gary L. Francis, glfrancis@vcu.edu
}

Received 1 November 2011; Accepted 1 November 2011

Copyright ( $) 2011$ R. Brown and G. L. Francis. This is an open access article distributed under the Creative Commons Attribution License, which permits unrestricted use, distribution, and reproduction in any medium, provided the original work is properly cited.

Thyroid autoimmunity, as reflected by the presence in serum of autoantibodies directed against the thyroid autoantigens thyroglobulin (Tg) and thyroid peroxidase (TPO), is present in $>10 \%$ of the US population over 12 years of age [1] and is the most common cause of endocrine dysfunction in iodinesufficient populations [2]. The underlying mechanism is a failure of T-cell tolerance leading to lymphocytic infiltration of the thyroid gland [3] and to a complex sequence of humoral and cellular immune responses to thyroid antigens, presumably in response to an environmental trigger [4]. In chronic lymphocytic thyroiditis (CLT), the predominant immunologic mechanisms are T-cell- and cytokinemediated thyroid cell damage and apoptotic cell death whereas in Graves' disease (GD) generation of thyrotropin (TSH) receptor autoantibodies leads to thyroid cell stimulation [5], but significant overlap exists. Seven susceptibility genes, in addition to the major histocompatibility gene (HLA-DR3), have now been identified [6]. Some of these genes affect the immune response in general (CD40, CTLA-4, and PTPN22), while others are thyroid specific (thyroglobulin, thyrotropin (TSH) receptor). Some are common to both CLT and GD, while others are specific for GD.

In view of the importance of AITD as well as the diverse array of new information, it is only fitting that this special issue of the Journal of Thyroid Research is devoted entirely to this complex subject. Four of the papers we have selected are focused on clinical topics, including AITD in childhood, during pregnancy, in the postpartum period, and in patients with type 1 diabetes mellitus. The fifth paper addresses the potential role of NKT cells in an animal model of thyroiditis.

We conclude this special edition with a discussion of thyroid autoimmunity in patients with papillary thyroid cancer (PTC). The association of AI and thyroid cancer was first reported by Dailey et al. [7]. In general, patients with AI appear more likely to have PTC than follicular thyroid cancer (FTC), but a lower frequency of extrathyroidal extension, nodal and distant metastases when compared with patients without AI. In some but not all series, patients with autoimmune thyroiditis (AT) and PTC have improved survival when compared to those with PTC alone, suggesting that thyroid autoimmunity might contribute to improved survival [8-10]. In contrast, other data suggest that AI might actually increase the risk to develop thyroid cancer [10$12]$.

Several theories have been proposed to explain how AI might increase the risk for thyroid malignancy. Thyrocyte apoptosis and proliferation are increased in AI suggesting that thyrocytes rapidly progressing through the cell cycle might accumulate increased DNA damage resulting in malignant transformation [13]. Russell et al. hypothesized that thyroid cells predestined to become cancers might secrete proinflammatory cytokines that affect immune cells [14]. They showed that thyrocytes of ret/PTC3 transgenic mice express increased levels of interleukins, tumor necrosis factor- $\alpha$, and cyclooxygenase-2 [14] that could attract and/or activate cells of the immune system. Finally, the ret/PTC recombinant genes have been detected in samples of AI [1517] suggesting that ret/PTC rearrangements might be present in AI and could be precursors to PTC.

From these papers, it is clear that thyroid autoimmunity is a frequent problem in the population and that thyroid autoimmunity can lead to a variety of thyroid disorders including alterations in thyroid hormone synthesis and possibly even neoplasia. Focused research in this area is 
beginning to illuminate some of the molecular mechanisms that help to explain these associations.

Rosalind Brown

Gary L. Francis

\section{References}

[1] M. I. Surks and J. G. Hollowell, "Age-specific distribution of serum thyrotropin and antithyroid antibodies in the U.S. population: implications for the prevalence of subclinical hypothyroidism," Journal of Clinical Endocrinology and Metabolism, vol. 92, no. 12, pp. 4575-4582, 2007.

[2] A. Huber, F. Menconi, S. Corathers, E. M. Jacobson, and Y. Tomer, "Joint genetic susceptibility to type 1 diabetes and autoimmune thyroiditis: from epidemiology to mechanisms," Endocrine Reviews, vol. 29, no. 6, pp. 697-725, 2008.

[3] A. P. Weetman, "Cellular immune responses in autoimmune thyroid disease," Clinical Endocrinology, vol. 61, no. 4, pp. 405413, 2004.

[4] R. S. Brown, "Autoimmune thyroid disease: unlocking a complex puzzle," Current Opinion in Pediatrics, vol. 21, no. 4, pp. 523-528, 2009.

[5] B. R. Smith, J. Sanders, and J. Furmaniak, "TSH receptor antibodies," Thyroid, vol. 17, no. 10, pp. 923-938, 2007.

[6] D. C. Eschler, A. Hasham, and Y. Tomer, "Cutting edge: the etiology of autoimmune thyroid diseases," Clinical Reviews in Allergy and Immunology, vol. 41, no. 2, pp. 190-197, 2011.

[7] M. E. Dailey, S. Lindsay, and R. Skahen, "Relation of thyroid neoplasms to Hashimoto disease of the thyroid gland," A.M.A. Archives of Surgery, vol. 70, pp. 291-297, 1955.

[8] S. L. Souza, L. V. Montalli da Assumpcao, and L. S. Ward, "Impact of previous thyroid autoimmune diseases on prognosis of patients with well-differentiated thyroid cancer," Thyroid, vol. 13, no. 5, pp. 491-495, 2003.

[9] K. Kashima, S. Yokoyama, S. Noguchi et al., "Chronic thyroiditis as a favorable prognostic factor in papillary thyroid carcinoma," Thyroid, vol. 8, no. 3, pp. 197-202, 1998.

[10] K. C. Loh, F. S. Greenspan, F. Dong, T. R. Miller, and P. P. B. Yeo, "Influence of lymphocytic thyroiditis on the prognostic outcome of patients with papillary thyroid carcinoma," Journal of Clinical Endocrinology and Metabolism, vol. 84, no. 2, pp. 458-463, 1999.

[11] E. Kebebew, P. A. Treseler, P. H. G. Ituarte, and O. H. Clark, "Coexisting chronic lymphocytic thyroiditis and papillary thyroid cancer revisited," World Journal of Surgery, vol. 25, no. 5, pp. 632-637, 2001.

[12] D. M. Tamimi, "The association between chronic lymphocytic thyroiditis and thyroid tumors," International Journal of Surgical Pathology, vol. 10, no. 2, pp. 141-146, 2002.

[13] I. Okayasu, M. Fujiwara, Y. Hara, Y. Tanaka, and N. R. Rose, "Association of chronic lymphocytic thyroiditis and thyroid papillary carcinoma: a study of surgical cases among Japanese, and white and African Americans," Cancer, vol. 76, no. 11, pp. 2312-2318, 1995.

[14] J. P. Russell, J. B. Engiles, and J. L. Rothstein, "Proinflammatory mediators and genetic background in oncogene mediated tumor progression," Journal of Immunology, vol. 172, no. 7, pp. 4059-4067, 2004.

[15] S. Arif, A. Blanes, and S. J. Diaz-Cano, "Hashimoto's thyroiditis shares features with early papillary thyroid carcinoma," Histopathology, vol. 41, no. 4, pp. 357-362, 2002.

[16] C. L. Fenton, Y. Lukes, D. Nicholson, C. A. Dinauer, G. L. Francis, and R. M. Tuttle, "The ret/PTC mutations are common in sporadic papillary thyroid carcinoma of children and young adults," Journal of Clinical Endocrinology and Metabolism, vol. 85, no. 3, pp. 1170-1175, 2000.

[17] Y. E. Nikiforov, "Spatial positioning of RET and H4 following radiation exposure leads to tumor development," The Scientific World Journal, vol. 1, pp. 186-187, 2001. 


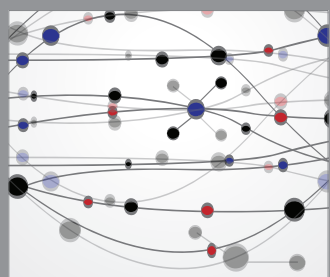

The Scientific World Journal
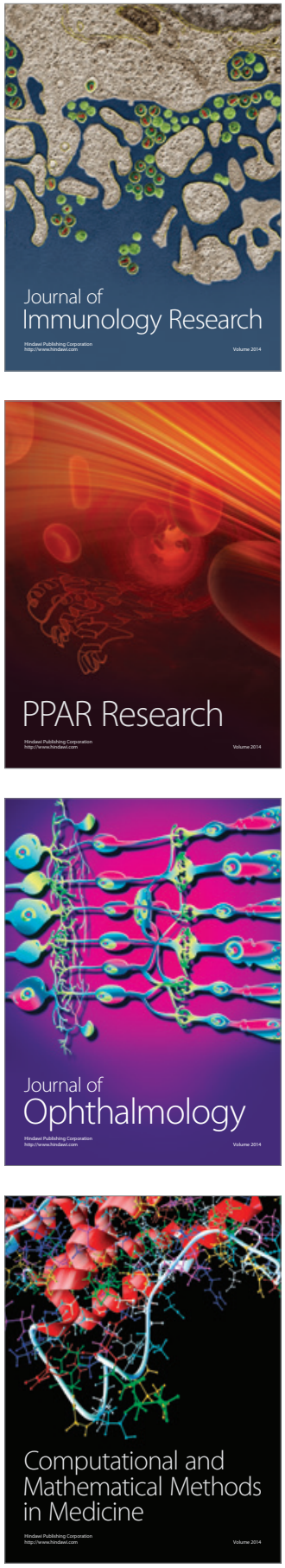

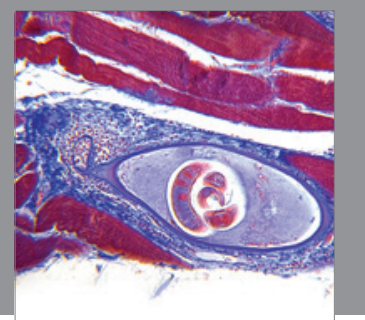

Gastroenterology

Research and Practice
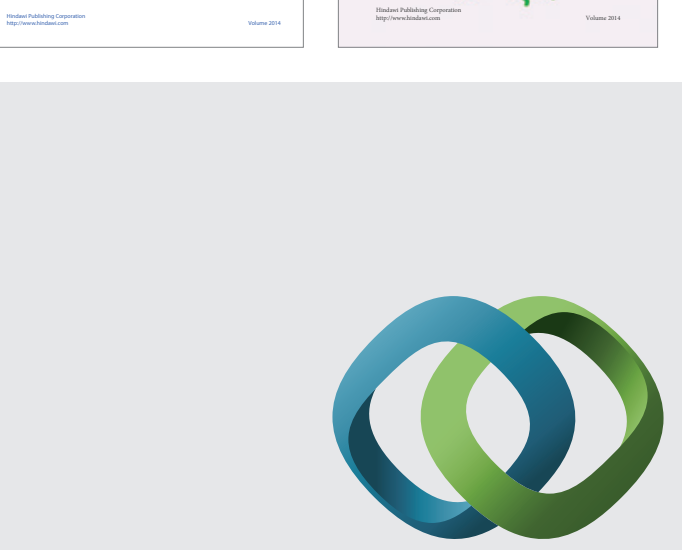

\section{Hindawi}

Submit your manuscripts at

http://www.hindawi.com
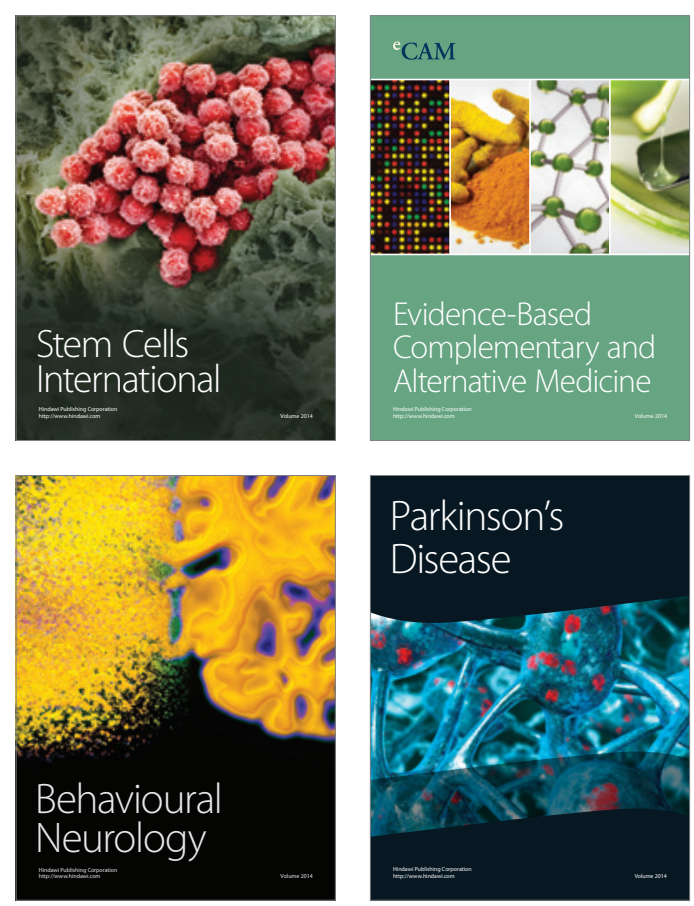

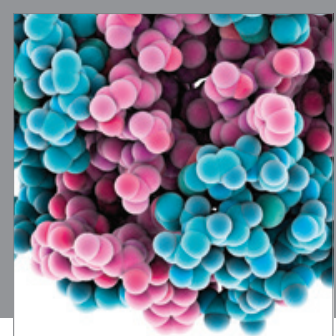

Journal of
Diabetes Research

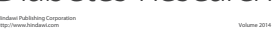

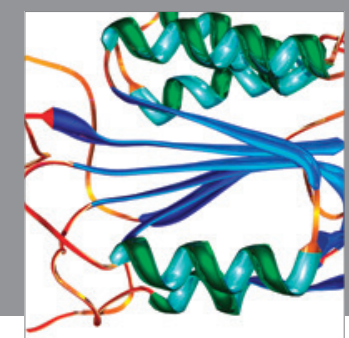

Disease Markers
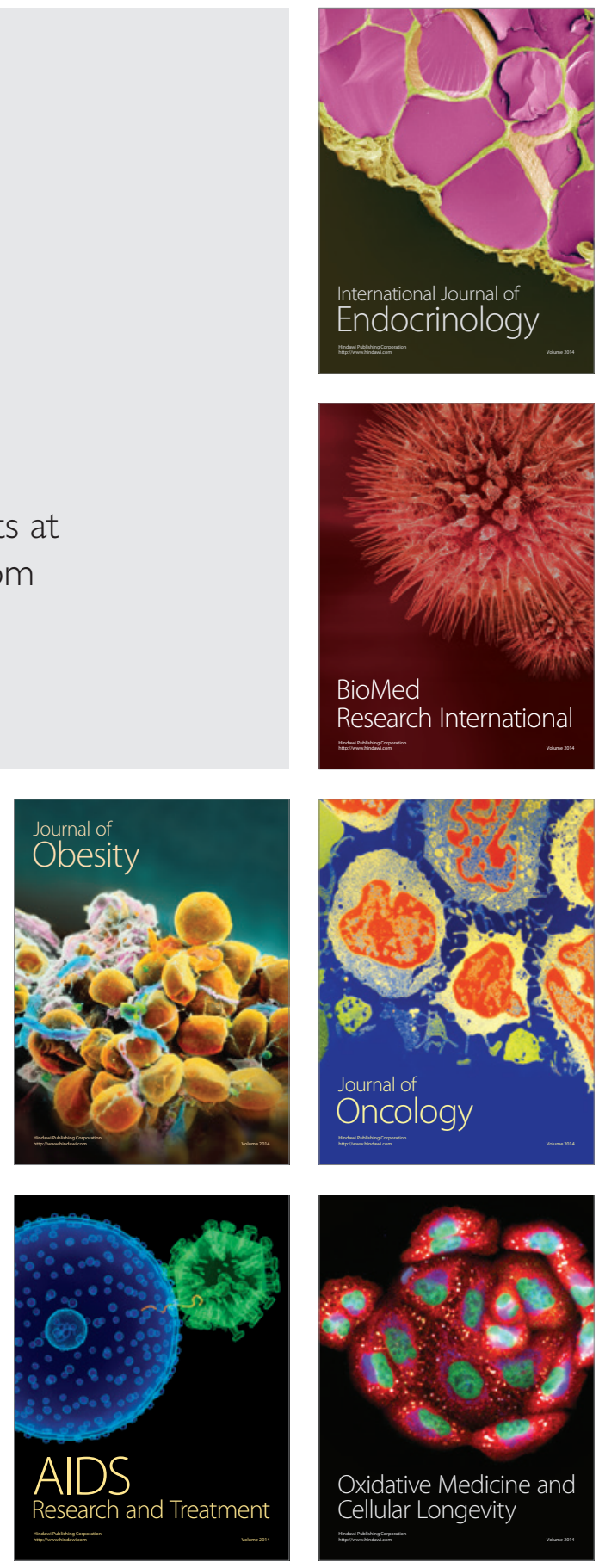